\title{
QUALITY OF LIFE OF THE ELDERLY POPULATION DURING \\ THE VIRUS COVID-19 PANDEMIC WITH SPECIAL REFERENCE TO AGRICULTURISTS
}

\author{
Pavle Radanov ${ }^{1}$, Ivana Lešević ${ }^{2}$, Pavle Brzaković ${ }^{3}$, Dragan Pajić ${ }^{4}$ \\ *Corresponding authorE-mail: ivana.skenderovic@mef.edu.rs
}

A R T I C LE IN F O

Original Article

Received: 07 October 2020

Accepted: 08 December 2020

doi:10.5937/ekoPolj2004155R

UDC

005.336.3:314.114:[614.4:631

\section{Keywords:}

Covid-19, quality of life, elderly population, agricultural activities, movement ban

JEL: I18, I38, Q10, R0

\begin{abstract}
A B S T R A C T
In the Republic of Serbia, on March 15 ${ }^{\text {th }}, 2020$ Government decided to declare a state of emergency due to the Covid-19 pandemic. One of the measures was a movement ban for people over 65 in urban areas and those over 70 in rural areas. This research should indicate how people over 65 in urban areas have endured this situation, especially in relation to the same population in rural areas, as well as implications of the movement ban on the quality of life of the elderly population. Special importance is given to the rural population engaged in agriculture. A tool of data collection in this research was anonymous survey. Respondents' answers were statistically processed, which led to clear conclusions about the large negative consequences for the elderly population, including the agricultural activities in rural areas. Covid-19 is still present, which opens further questions related to the quality of life of the elderly population, if necessity for similar measures recurs in the future.
\end{abstract}

(C) 2020 EA. All rights reserved.

1 Pavle Radanov, PhD, Associate. Professor, University Business Academy in Novi Sad, Faculty of Applied Management, Economics and Finance, Jevrejska 24/1, Belgrade, Phone: +381 6686649 00, E-mail: pavle.radanov@mef.edu.rs, ORCID ID (https://orcid.org/00000003-4657-1995)

2 Ivana Lešević, PhD, Foreign Language Teacher, University Business Academy in Novi Sad, Faculty of Applied Management, Economics and Finance, Jevrejska 24/1, Belgrade, Phone: +381 6424806 10, E-mail: ivana.skenderovic@mef.edu.rs, ORCID ID (https:// orcid.org/0000-0002-4820-7946)

3 Pavle Brzakovic, PhD, Asst. Professor, University Business Academy in Novi Sad, Faculty of Applied Management, Economics and Finance, Jevrejska 24/1, Belgrade, Phone: +381 6432902 55, E-mail: pavle.brzakovic@mef.edu.rs, ORCID ID (https://orcid.org/00000001-5184-9627)

4 Dragan Pajić, Msc. Ecc., Novi Sad Fair, Janka Čmelika 79, Novi Sad, Phone: +381 63512 558, E-mail: dragan.pajic@sajam.net, ORCID ID (https://orcid.org/0000-0003-1017-0495) 


\section{Introduction}

Due to the difficult epidemiological situation in the world caused by the Covid-19 virus, and in order to protect the health of entire population, Serbian Government prohibited on March $15^{\text {th }}$ movement to the citizens over 65 year in urban areas and those over 70 in rural areas. For the rest of the population the ban was in effect firstly from $8 \mathrm{pm}$ to 5 am every day, but later measures were tightened, and the bans included hours from $5 \mathrm{pm}$ to $5 \mathrm{am}$ the next day, as well as all-day weekend bans. Those who were on work assignments had special movement permits.

The population over 65 was enabled to go out once a week in the period from 4 o'clock to 7 o'clock in the morning, with obligatory preventive measures such as wearing masks and gloves, as well as keeping physical distance, to purchase necessities for the next seven days. From April 21 $1^{\text {st }}$, 2020, after being isolated for more than a month, the elderly population has been allowed to go out for half an hour three times a week.

The state of emergency in the Republic of Serbia was lifted on May $7^{\text {th }}, 2020$, at 5 am, after 53 days. In the new situation, people older than 65 are recommended to assess the risk of leaving the house based on the data on the epidemiological situation, which were regularly announced by experts through the media.

Socialization is an important part of human life, as well as phycological aspect of every individual or to use words of N. Rot (2014): "[...] culture and society to which an individual belongs are the basic source of socialization. Socialization is achieved through the actions of other persons and institutions that are factors through which society seeks to adopt certain forms of behaviour." On the other hand, the isolation of every kind makes people feel stressed and uncomfortable, even more so when it comes to global health threat. It is a difficult situation for the majority. However, in the general population there are sensitive groups, which are affected by the pandemic and the isolation more and harder, even more so if they are not treated equally. The inequalities are significant problem of modern life, but "the happenings during the pandemic have shed light on the inequalities in the society. In general understanding, discriminative attitudes towards some group of people on the grounds of economic properties, race or ethnicity, age, and gender occupies the first steps on the ladder of social inequalities." (Kiran, 2020) The United Nations (2020) presented the same list of vulnerable groups, that face extreme difficulties during the pandemic. These are poor, women, migrants, elderly, etc. The last category is the main point of this paper, bur firstly it is very important to define who belongs to this category. "According to the psycho-pedagogical area, entering the category of elderly people means having an age ranging from 65 years upwards. Psycho-pedagogical scholars have divided this macro category of the elderly into 4 micro categories: young elderly people from 65 to 74 years old, elderly people from 75 to 84 years old, elderly adults from 85 to 99 years old and centenarians from 100 years upwards." (Cirilli et al., 2020) However, the majority of older population belongs to the generation of so-called "baby boomers, born between 1946 and 1964 and until recently dominated the labour market" (Murphy, 
2007) and now feeling powerless and lonely and not only, "the ageist attitudes towards them is worsening this already harsh situation for them" (Kendall-Taylor et al., 2020). Considering that fact it is reasonable to assume that the elderly population is a particularly sensitive part of the nation and that the effects of the unusual situation in society (pandemic and isolation) are multiple. It is however important to explain why the over 65 are that vulnerable. According to the Simić et al. (2007) "in old age there can be a change in thinking (cognition), memory, in the personality and its mood and behaviour. Set a boundary between diseases and normal processes are often not easy, e.g. reducing or slowing down the mental process can be seen as a consequence age, and what in essence can be a consequence of diseases that are successfully treated (e.g. depression, hypothyroidism)." That is why the isolation, added to the common threat of the virus can worsen the life quality of old people. "Feeling of being lonely diminishes the strength of the immune system which is already not that strong in old people" (Solomon, 2020), but also "this may give the feeling of being a threat to the wellbeing of the family and society to the elderly (Koon, 2020).

This is not an issue regarding a small percentage of the population. "We live in a time of aging population. Due to advances in medicine and health care, life expectancy is being extended" (Tokić et al., 2017), but also there is a significant problem with a low rate of natural increase, which makes Serbia a country of elderly.

However, Serbia is also a rural country. "Rural areas of the Republic of Serbia are characterized by unfavourable demographic trends, insufficient diversification of activities, inadequate equipment with infrastructure and other important elements necessary for development. Regional differences are large, so it occurs through economic, financial, socio-cultural, environmental and other related problems. Rural areas cover over $96 \%$ of settlements (over $78 \%$ of the area of the Republic of Serbia)." (Ritić et al., 2020) It is obvious that pandemic made the unfavourable situation more difficult. It is necessary therefore to understand what differences are, if there are any, in the life quality of elderly in cities and countryside.

"It can be observed that older people are increasingly viewed with a certain stigmatization of consumers of social resources because the condition of the elderly is associated with weaknesses, fragility and disease; which leads to the notion of unproductivity, so old age is understood as a source of economic burden for the community." (Vuletić at al., 2018) However, when it comes to the rural population, the fact that it is the elderly population does not necessarily mean that it is not the working population. A large number of rural residents are actively engaged in agriculture, either for their own needs or as a form of business activity.

The Covid-19 pandemic raised a question regarding country life and urban living. As Božilović and Petković rightly observe (2020) "in recent months, a discourse has emerged in the public that links the pandemic to cities, labelling those cities as the places responsible for its outbreak and rapid spread", while "the village is seen as a safer (healthier) place to live, which in an emergency provides more opportunities 
to stay outdoors, and thus more meaningful leisure time compared to the city." It is reasonable to assume that the situation is not that simple and that there are difficulties in dealing with the uncertainty of the pandemic in both cities and villages.

Therefore, the research aimed to show the social, economic and psychological implications of multi-day quarantine on the population older than 65 years in the cities and 70 years in rural areas, as well as whether there is a difference in lifestyle of the elderly population between towns and villages after isolation. In addition, the aim was to show how the movement ban affected agricultural activities in rural areas.

\section{Materials and methods}

The research conducted in five urban and five rural areas on a sample of a total of 1000 respondents concerns the quality of life of the population older than 65 and 70 during the state of emergency. Aspects that were considered were health and psychological condition, financial situation and social life.

The research was conducted with the aim to determine the extent of the already mentioned isolation during the state of emergency on the elderly population, but also to determine the potential differences in the consequences of this way of life between the rural and urban population.

The main hypothesis assumes that the consequences of isolation during the state of emergency left significant negative consequences on the population older than 65 and 70 years. The auxiliary hypothesis, on the other hand, assumes that the population over the age of 65 experienced emergency measures in the city in a different way in relation to the village population, i.e. that the negative consequences were less felt in rural areas. The second auxiliary hypothesis concerns the agricultural activities of the rural population, and the assumption is that the movement ban had a negative impact on this aspect of life as well.

The method of data collection implies the so-called "first-hand data collection" (Singleton, Straits, 2018). In this case it was an anonymous survey. The aim was to collect data of the quantitative type, which is considered an adequate tool in the case of this primarily sociological research, where "sociological survey is one of the main methods of quantitative research" (Bryman, 2006). This particular research is an example of "socio-psychological (values, lifestyles, habits) survey research" (Fajgelj, 2020). Considering the topic, this way of data collection was important because "any data collection through conversation turns into a certain social relationship, which in the methodology is considered from the point of view of creating scientifically usable information, as the main goal" (Milić, 1996).

The main purpose of the research is to gather information on how citizens older than 65 and 70, respectively, who were forbidden to move during the state of emergency, endured quarantine, having in mind the social and economic circumstances, as well as the psychological and health condition of the respondents. 
The survey was conducted in the period from May $16^{\text {th }}, 2020$ to June $6^{\text {th }}, 2020$. The survey included 1000 respondents, citizens of the Republic of Serbia of different genders and education. The survey was conducted in five cities and five villages in different parts of the Republic of Serbia, and in each of them there were 500 respondents.

During the survey, which was conducted by telephone, researchers used a questionnaire containing ten questions with 4 or 3 answers offered. They were asked to all respondents, while the respondents from rural areas were asked additional five questions related to agricultural activities.

Questions used in the survey are as following:

1. Did you respect quarantine measures during the state of emergency?

2. What is your health condition after quarantine compared to the previous period?

3. How did you spend your time during quarantine?

4. What is your financial situation after quarantine?

5. What bothered you the most during quarantine?

6. What did you miss the most during quarantine?

7. How did you procure necessities during quarantine?

8. How would you rate your life during quarantine?

9. Has your life returned to the previous state after the quarantine was lifted?

10. What is the quality of your life after quarantine?

Additional questions for respondents from rural areas:

1. Are you engaged in agriculture?

2. Did you perform agricultural activities during the movement ban?

3. Are you late with agricultural work?

4. Has the movement ban affected your agricultural activities?

5. Will you be able to make up for what you missed / were late in the field works?

\section{Results}

After the survey, questionnaires were collected and processed, and the presentation of the results was made in a tabular method. Total number of respondents is 1000, 500 in rural areas and 500 in urban areas.

Table 1. Did you respect quarantine measures during the state of emergency?

\begin{tabular}{|c|c|c|}
\hline & Urban areas & Rural areas \\
\hline Answers & Number of answers & Number of answers \\
\hline Yes & 374 & 420 \\
\hline Partly & 114 & 80 \\
\hline No & 12 & 0 \\
\hline
\end{tabular}

Source: Authors, 2020 
Table 2. What is your health condition after quarantine compared to the previous period?

\begin{tabular}{|c|c|c|}
\hline & Urban areas & Rural areas \\
\hline Answers & Number of answers & Number of answers \\
\hline Better & 0 & 0 \\
\hline Worse & 325 & 41 \\
\hline Same & 175 & 459 \\
\hline
\end{tabular}

Source: Authors, 2020

Table 3. How did you spend your time during quarantine?

\begin{tabular}{|c|c|c|}
\hline & Urban areas & Rural areas \\
\hline Answers & Number of answers & Number of answers \\
\hline Watching TV, reading books... & 262 & 97 \\
\hline Courtyard / balcony & 43 & 400 \\
\hline Telephone, computer, social media... & 195 & 3 \\
\hline
\end{tabular}

Source: Authors, 2020

Table 4. What is your financial situation after quarantine?

\begin{tabular}{|c|c|c|}
\hline & Urban areas & Rural areas \\
\hline Answers & Number of answers & Number of answers \\
\hline Better & 500 & 500 \\
\hline Worse & 0 & 0 \\
\hline Same & 0 & 0 \\
\hline
\end{tabular}

Source: Authors, 2020

Table 5. What bothered you the most during quarantine?

\begin{tabular}{|l|c|c|}
\hline \multicolumn{1}{|c|}{ Answers } & Urban areas & Rural areas \\
\hline Loneliness & Number of answers & Number of answers \\
\hline Impossibility to take a walk & 140 & 0 \\
\hline Problem in grocery procurement & 222 & 0 \\
\hline Fear & 105 & 396 \\
\hline
\end{tabular}

Source: Authors, 2020

Table 6. What did you miss the most during quarantine?

\begin{tabular}{|c|c|c|}
\hline & Urban areas & Rural areas \\
\hline Answers & Number of answers & Number of answers \\
\hline Children, grandchildren... & 353 & 500 \\
\hline Going out & 141 & 0 \\
\hline Pre quarantine routine & 0 & 0 \\
\hline Sense of freedom & 6 & 0 \\
\hline
\end{tabular}

Source: Authors, 2020 
Table 7. How did you procure necessities during quarantine?

\begin{tabular}{|c|c|c|}
\hline & Urban areas & Rural areas \\
\hline Answers & Number of answers & Number of answers \\
\hline $\begin{array}{c}\text { Once a week when it was } \\
\text { allowed }\end{array}$ & 165 & 61 \\
\hline $\begin{array}{c}\text { It was being done by family } \\
\text { members }\end{array}$ & 253 & 388 \\
\hline It was being done by neighbours & 76 & 51 \\
\hline $\begin{array}{c}\text { Paying delivery or someone to } \\
\text { do it }\end{array}$ & 6 & 0 \\
\hline
\end{tabular}

Source: Authors, 2020

Table 8. How would you rate your life during quarantine?

\begin{tabular}{|c|c|c|}
\hline & Urban areas & Rural areas \\
\hline Answers & Number of answers & Number of answers \\
\hline Good & 76 & 301 \\
\hline Medium & 190 & 199 \\
\hline Bad & 234 & 0 \\
\hline
\end{tabular}

Source: Authors, 2020

Table 9. Has your life returned to the previous state after the quarantine was lifted?

\begin{tabular}{|c|c|c|}
\hline & Urban areas & Rural areas \\
\hline Answers & Number of answers & Number of answers \\
\hline Yes & 160 & 471 \\
\hline Partly & 125 & 29 \\
\hline No & 215 & 0 \\
\hline
\end{tabular}

Source: Authors, 2020

Table 10. What is the quality of your life after quarantine?

\begin{tabular}{|c|c|c|}
\hline & Urban areas & Rural areas \\
\hline Answers & Number of answers & Number of answers \\
\hline Better & 0 & 0 \\
\hline Worse & 362 & 118 \\
\hline Same & 138 & 382 \\
\hline
\end{tabular}

Source: Authors, 2020

Table 11. Are you engaged in agriculture?

\begin{tabular}{|c|c|}
\hline Answers & Number of answers \\
\hline Yes, I have agricultural holding & 237 \\
\hline Only for our own needs & 263 \\
\hline No & 0 \\
\hline
\end{tabular}

Source: Authors, 2020 
Table 12. Did you perform agricultural activities during the movement ban?

\begin{tabular}{|c|c|}
\hline Answers & Number of answers \\
\hline Yes, with a movement permit & 259 \\
\hline Yes, without movement permit & 171 \\
\hline No & 70 \\
\hline
\end{tabular}

Source: Authors, 2020

Table 13. Are you late with agricultural work?

\begin{tabular}{|c|c|}
\hline Answers & Number of answers \\
\hline Yes & 423 \\
\hline No & 77 \\
\hline
\end{tabular}

Source: Authors, 2020

Table 14. Has the movement ban affected your agricultural activities?

\begin{tabular}{|c|c|}
\hline Answers & Number of answers \\
\hline Yes (we haven't done all the work) & 394 \\
\hline No (we have done everything as planned) & 106 \\
\hline
\end{tabular}

Source: Authors, 2020

Table 15. Will you be able to make up for what you missed / were late in the field works?

\begin{tabular}{|c|c|}
\hline Answers & Number of answers \\
\hline Yes & 290 \\
\hline $\mathrm{Ne}$ & 210 \\
\hline
\end{tabular}

Source: Authors, 2020

\section{Discussions}

Looking at the results of the survey, it can be seen, above all, that senior citizens largely respected the Government measures during the state of emergency, although more of them did so in rural areas. It is also obvious that the consequences of isolation are ubiquitous, especially when it comes to the health of elderly citizens, because $36.6 \%$ of the respondents assessed their health as worse compared to the previous period, and while $63.4 \%$ answered that their health is the same. However, it must be noted that the health of the population in rural areas is far better, as only 41 respondents felt worse. There are big differences in the way the residents of cities and villages spent their time. While most of the respondents from rural areas spent time outside the house (yard, balcony), in the city it was with television, books or computers.

An element about which there is no doubt is the financial situation, where even an incredible $100 \%$ of respondents claimed that their financial situation was better. It can be assumed that this was influenced by two types of assistance from the Government of the Republic of Serbia (100 Euros to all adult citizens and a one-time assistance of 4,000 RSD to pensioners). 
It is known, and so the literature testifies, that the third age is especially sensitive to loneliness: "especially old age, is the last critical phase when loneliness is put to a decisive test. Man in all his life so far - either fully conceived, or only partially fulfilled, or in an objective balance assessed as missed and empty - now enters into possible loneliness and preparation for death, calm and cheerful, or perceives his loneliness as the worst curse in the world." (Jerotić, 2011) Therefore, it is important to pay attention to how quarantine affected the psychological state of the elderly population, because as many as $85.3 \%$ of respondents said that they mostly lacked contact with loved ones, and only then walking in urban areas, while in the village the only discomfort was impossibility to maintain close contact with family, even despite the fact that they stated that mostly children were those who brought them basic necessities of life. It is also noticeable that a large number of elderly people went shopping in the city alone in relation to the village where elderly related on others. It can be seen that the city itself "largely shapes the statuses, resources, identities and actions of individuals and social groups as urban actors" (Vujović, Petrović, 2005).

We can finally conclude that the quality of life of the rural population after isolation is significantly higher compared to the urban population, as well as that they returned to everyday life faster. "Village and city are two different historically formed socio-spatial forms of human existence that are culturally complementary" (Mitrović, 1995). It is clear, therefore, that two different ways of life influenced how the elderly will cope with the state of emergency, what consequences it will leave on them.

However, although the rural population in some way relieved itself of the quarantine situation, the question of agricultural activities arose. Agriculture is the only income for a good part of this population. As expected, all respondents stated that they are engaged in agriculture, some of them have farms, while there are slightly more of them who work in field for their own needs. Slightly more than half of the respondents obtained movement permits for field works, issued by the Ministry of Agriculture, while a not insignificant number performed activities without permits, as many as 171 . A small part gave up work during the movement ban and it is worth to emphasize that these are all persons who have agricultural production for their own needs. The vast majority was late with agricultural work and failed to do all the planned activities. Asked whether they will be able to recover from the consequences of the quarantine, slightly more than half said they will, while the rest are permanently behind this year. It must be pointed out that those who produce for their own needs will recover first, while larger farms are in a bigger problem.

One should pay attention here to one interesting phenomenon. Asked whether they complied with the measures, the villagers all answered that they did, with 80 stating that they complied with the measures in part. On the other hand, 171 of them stated that they violated the movement ban and performed work in the field without a permit. One logical conclusion is imposed: working in the field for a Serbian peasant is a must, inviolability, an obligation, and they do not understand their agricultural activities as 
something that can violate any rule. The land will not wait, and the peasant will not let it wait. It is true that the movement permits of peasants for the sake of work in the field were regulated at some point and the ban did not apply to them. However, there was the first period when the farmers and his needs were not considered and when the ban was valid for them as well. On the other hand, the question is whether they were informed in the right way how to obtain permits, whether they master the technology, have access to the Internet and the like, since the applications for permits were submitted electronically.

This research used a survey when collecting data and it allowed that "in addition to objective data, survey research to collect data on mental or psychophysical characteristics, moods, emotions, etc." (Fajgelj, 2020). There is a great opportunity for further research when one could go deeper into each of the previous points and examine in more detail the motivation of the given answers. In addition, it would be advisable to return to these issues after a certain time, in order to analyse the consequences from a greater time distance.

\section{Conclusions}

The year 2020 brought great worries on a global level and consequently great changes. The pandemic of Covid-19 virus disrupted the world order in every segment. The Republic of Serbia was no exception and at the beginning of March this year, the first case of this contagious disease was registered. In order to bring the spread of the virus under control, the Government of the Republic of Serbia introduced a series of measures, with the goal and hope to prevent further illness of the population. One of the first measures was the movement ban to the population older than 65 in urban areas or older than 70 years in rural areas.

Having in mind the fact that the elderly population is the most vulnerable in terms of health, and that these measures were adopted for that very reason, the question arose how such part of society endured the period of isolation, and what are the consequences for older citizens.

The conducted research primarily concerns the quality of life of seniors in our society, starting from the health aspect, through the psychological state to financial stability. However, as the measures were taken distinguishing the urban from the rural population, and due to completely different ways of life, it was reasonable to assume that the emergency measures would have different effects on the inhabitants of urban areas and the inhabitants of rural settlements. In addition to the already mentioned elements, the rural population had face with the difficulties of performing agricultural work, which is an important part of their lives, and often the only income.

The research, which included ten questions (and additional five questions for rural population) with offered answers, concerned the quality of life in the already mentioned aspects. The survey was conducted by telephone and the respondents did not provide any personal data, except for age and gender. Their answers, however, are extremely personal, as most of the questions reflect their emotional states and personal attitudes. 
The results, given in tables on the previous pages, confirmed that all the assumptions, i.e. hypotheses, proved to be correct. The movement ban significantly affected the quality of life of the elderly population in a negative context. Health and mental condition were assessed as worse in most cases, which testifies to the far-reaching isolation, loneliness, lack of movement, reduced social interaction, familiarity with a type of routine that did not depend on them. The only thing that is unequivocally assessed as an improvement is the financial situation, which may be a consequence of the measures of financial assistance of the Government of the Republic of Serbia. The second hypothesis, related to different ways of enduring the state of emergency among the citizens of the city and the village, has been confirmed. The rural population evaluated the quality of life as better in relation to the urban population, and the return to normal life was faster and more harmless. The same is the case with the third hypothesis, which concerned the negative impact of the movement ban on agricultural activities.

It is extremely important to consider the results of the research in order to try to improve the lives of over 65 population. The elderly people are vulnerable as it is and, as it has been shown, it is necessary to work harder to improve their position. Even in the pre Covid-19 world this part of the population needed intergenerational solidarity that comprehends "support and cooperation between different age groups and is demonstrated through enabling equal social inclusion and participation of people over the age of 65, in order to have a dignified aging and a sense of self-esteem" (Todorović, Vračević, 2015). "Finally, a sense of security and adequate financial circumstances are most important basis for good adaptation to old age. In favourable mental conditions and social climate, where it is not under the impact of poverty, discrimination and segregation, the population of the elderly may be well integrated, satisfied with her social place and role and on its own way constructive." (Poleksić, 1979) As it was said, but it is worth repeating, all this elements are irreplaceable for the oldest part of the population to feel secure and live with dignity. But now more that ever it is crucial to consider what they feel and what they need. That is why this research tries to highlight the importance of the given topic and initiate fellows researcher to do the same, as well as the authorities to consider all aspect of the life of our oldest when adopting anti Covid-19 measures.

The significance of this topic is just beginning to be seen, since the events that were the subject of this research have taken place recently and, as it seems, they are still happening. It is necessary, it can be assumed, for a certain period to pass in order to determine the extent of the consequences of quarantine for the elderly population. Also, with the time distance, and therefore emotional, the respondents could give different answers, and comparative analysis could lead to new findings. However, at the time of writing this paper, the situation with the epidemic has once again started to worsen, after a brief calm period. Virus is not extinguished, and the experts are arguing about the potential return of certain measures. For this reason, it is extremely important to point out the problems of the elderly population and keep in mind what the consequences may be in the event of the need for similar measures in the future. 


\section{Conflict of interests}

The authors declare no conflict of interest.

\section{References}

1. Božilović J. \& Petković J. (2020). Sociourbani aspekti pandemijske krize u Srbiji. Sociološki pregled, 54(3), 837-863. [in English: Božilović J. \& Petković J. (2020). Socio-urban aspects of pandemic crisis in Serbia. Sociological Review. 54(3), $837-$ 863]. https://doi.org/10.5937/socpreg54-27603

2. Bryman, A. (2006). Quantity and Quality in Social Research. London: Unwin Hyman.

3. Cirilli, E. \& Nicolini, P. (2020). Elderly people, Covid-19 and technologies: a qualitative research. $12^{\text {th }}$ International Conference on Education and New Learning Technologies, 8401-8410.

4. Fajgelj, S. (2020). Metode istraživanja ponašanja. Beograd: Centar za primenjenu psihologiju. [in English: Fajgelj, S. (2020). Methods of behaviour research. Belgrade: Centre of Applied Psychology]

5. Jerotić, V. (2011). Čovek i njegov identitet. Beograd: Zadužbina Vladete Jerotić. [in English: Jerotić, V. (2011). Man and His Identity. Belgrade: Foundation of Vladeta Jerotić]

6. Kendall-Taylor, N., Neumann, A. \& Schoen, J. (2020). Advocating for age in an age of uncertainty. Stanford social innovation review. Retrived from https://ssir. org/articles/entry/advocating_for_age_in_an_age_of_uncertainty (December 7th 2020)

7. Kiran, E. (2020). Prominent Issues About The Social Impacts of Covid-19. Journal of Social Sciences, Special Issue, 752-766. https://doi.org/10.21547/jss.787779

8. Koon, O. E. (2020). The impact of sociocultural influences on the COVID-19 measures - reflections from Singapore. Journal of Pain and Syptom Management, 60(2), 90-92. https://doi.org/10.1016/j.jpainsymman.2020.04.022

9. Mitrović, M. (1995). Selo i grad - komplementarni društveno-kulturni obrasci. Glasnik Etnografskog muzeja SANU, 41-54 Beograd. [in English: Mitrović, M. (1995). Village and city - complementary socio-cultural patterns. Bulletin of the Ethnographic Museum of SANU, 41-54, Belgrade].

10. Milić, V. (1996). Sociološki metod. Beograd:Zavod za udžbenike i nastavna sredstva. [in English: Milić, V. (1996). Sociological Method. Belgrade: Institute for Textbooks and Teaching Aids].

11. Murphy, S. (2007). Leading a Multigenerational Workforce. Washington, D.C: AARP.

12. United Nations. (2020). A UN framework for the immediate socio-economic response to covid-19. Retreived from https://unsdg.un.org/sites/default/ files/2020-04/UN-framework-for-the-immediate-socio-economic-response-toCOVID-19.pdf (December 8, 2020)

13. Radanov, P., (2020). Strategija održivog razvoja. Beograd: Fakultet za primenjeni menadžment, ekonomiju i finansije. 
14. Ristić, L. \& Obradović, S. (2020). Poljoprivreda i ruralni razvoj u procesu pristupanja Republike Srbije Evropskoj uniji. Aktuelni makroekonomski $i$ mikroekonomski aspekti evropskih integracija Republike Srbije. Ekonomski fakultet Univerziteta u Kragujevcu, 43 - 60.

15. Poleksić, J. (1979). Zaštita duševnog zdravlja starih osoba. Beograd: Privrednofinansijski vodič. [In English: Poleksić, J. (1979). Protection of the mental health of the elderly. Belgrade: Economic and Financial Guide]

16. Rot, N. (2014). Osnovi socijalne prihologije. Beograd: Zavod za udžbenke i nastavna sredstva. [in English: Rot, N. (2014). Principals of Social Psihology. Belgrade: Institute For Textbooks And Teaching Aids].

17. Simić, S., Milovanović, S., Barišić, J., Crnobradić, C., Šikanić, N., Bajić, G. (2007). Starenje i psihološke promene. Engrami, 29(3-4), 77-85. [in English: Simić, S., Milovanović, S., Barišić, J., Crnobradić, C., Šikanić, N., Bajić, G. (2007). Old age and psychological changes. Engrami, 29(3-4), 77-85].

18. Singleton, R. A. \& Straits, B. C. (2018). Approaches to Social Research. New York: Oxford University Press.

19. Solomon, H. V. (2020). COVID-19 checklist: Mask, gloves, and video chatting with grandpa. Psychiatry Research, 288. Retrieved from https://www.sciencedirect. com/science/article/pii/S0165178120307563?via\%3Dihub (June 30, 2020).

20. Todorović, N. \& Vračević, M. (2015). Međugeneracijska solidarnost. Glas centra, 48(12), 43-54. [in English: Todorović, N. \& Vračević, M. (2015). Intergeneration solidarity. Voice of the centre, 48(12), 43-54].

21. Tokić, R. (2017). Kreativnost u trećoj životnoj dobi. Andragoški glasnik, 1-2, 7-25. [in English: Tokić, R. (2017). Creativity in the third age. Kreativnost u trećoj životnoj dobi. Andragogy Herald, 1-2, 7-25].

22. Vujović, S, \& Petrović, M. (2005). Urbana sociologija. Beograd: Zavod za udžbenke i nastavna sredstva. [in English: Vujović, S, i Petrović, M. (2005). Urban Sociology. Belgrade: Institute for Textbooks and Teaching Aids].

23. Vuletić, S., Juranić, B., Rakošec, Ž., Mikšić, Š., Jurić, K.A. (2018). Bioetičke inicijative revalorizacije starosti i starijih ljudi. Diacovensia, 26(3), 457-481. [in English: Vuletić, S., Juranić, B., Rakošec, Ž., Mikšić, Š., Jurić, K.A. (2018). Bioethical initiatives to revalue old age and older people. Diacovensia, 26(3), 457-481]. 